\title{
On and beyond traumatic fallout: unsettling political ecology in practice and scholarship
}

\author{
Alex A. Moulton ${ }^{a 1}$ \\ Stepha Velednitsky ${ }^{\mathrm{b}}$ \\ Dylan M. Harris ${ }^{c}$ \\ Courtney B. Cook ${ }^{d}$ \\ Brittany L. Wheeler ${ }^{\mathrm{e}}$ \\ ${ }^{a}$ University of Tennessee, Knoxville, USA \\ ${ }^{\mathrm{b}}$ University of Wisconsin-Madison, USA \\ ${ }^{\mathrm{c}}$ University of Colorado Colorado Springs, USA \\ $\mathrm{d}$ The University of Texas at Austin, USA \\ e Clark University, USA
}

\begin{abstract}
Franz Fanon poignantly argued that trauma is both an act and a memory of wounding that haunts subjects of violence. Addressing geographies of trauma, and the way that trauma is treated in the discipline of geography, is a matter of both theoretical and practical importance for critical human-environment scholars. However, discussions about uneven and ongoing geographies of trauma and violence - particularly in ways that enroll researchers themselves as agents within these landscapes - have been limited among political ecologists. When broached, these conversations are sometimes short-circuited by post-racial liberalism, whiteness or Eurocentricity, and academic respectability politics. This risks the continuance of logics that separate "researchers" from "communities" and lionize representational commitments to justice over material practices of transformation. In this article, we interrogate some of the theoretical and personal implications for political ecologists working with the legacies of dispossession, disruption, displacement and death. We draw on a wide collective of scholarship on haunting, hope, and geographies of trauma as well as our current work as geographers and educators. In the process, we build an argument for an approach that encourages unsettling, uncomfortable, and generative conversations about and beyond trauma. We end with three suggestions for engaging more substantively with the traumatic fallout that has long been at the center of political ecology.
\end{abstract}

Keywords: care, Black geographies, healing, hope, Indigenous Studies

\footnotetext{
${ }^{1}$ Dr. Alex A. Moulton is an Assistant Professor in the Department of Sociology at the University of Tennessee, Knoxville, USA. Email: amoulto3@utk.edu. Stepha Velednitsky is a Ph.D. student in the Department of Geography at the University of Wisconsin-Madison, USA. Dr. Dylan M. Harris is an Assistant Professor in the Department of Geography at the University of Colorado in Colorado Springs, USA. Dr. Courtney B. Cook received her PhD in Cultural Studies in Education from the University of Texas at Austin, USA and is currently working in the fields of public media, education, and documentary film as an Impact Producer with the PBS series POV. Brittany L. Wheeler is a Ph.D. Candidate in the Graduate School of Geography at Clark University in Worcester, Massachusetts, USA. Thank you to the JPE editor and anonymous reviewer for their constructive comments.
} 


\section{Résumé}

Franz Fanon a soutenu de manière poignante que le traumatisme est à la fois un acte et une mémoire de la blessure qui hante les sujets de la violence. Aborder les géographies du traumatisme, et la façon dont le traumatisme est traité dans la discipline de la géographie, est une question d'importance théorique et pratique pour les chercheurs critiques de l'environnement humain. Cependant, les discussions sur les géographies inégales et continues du traumatisme et de la violence - en particulier de manière à inscrire les chercheurs euxmêmes comme agents dans ces paysages - ont été limitées parmi les écologistes politiques. Lorsqu'elles sont abordées, ces conversations sont parfois court-circuitées par le libéralisme post-racial, la blancheur ou l'eurocentrisme, et les politiques de respectabilité académique. Cela risque de perpétuer des logiques qui séparent les "chercheurs" des "communautés" et qui privilégient les engagements de représentation de la justice par rapport aux pratiques matérielles de transformation. Dans cet article, nous nous interrogeons sur certaines des implications théoriques et personnelles pour les écologistes politiques qui travaillent sur les héritages de la dépossession, de la perturbation, du déplacement et de la mort. Nous nous appuyons sur un large collectif d'études sur la hantise, l'espoir et les géographies du traumatisme, ainsi que sur notre travail actuel en tant que géographes et éducateurs. Dans le processus, nous construisons un argument en faveur d'une approche qui encourage des conversations troublantes, inconfortables et génératives sur et au-delà du traumatisme. Nous terminons par trois suggestions pour s'engager de manière plus substantielle avec les retombées traumatiques qui ont longtemps été au centre de l'écologie politique.

Mots clés : soins, géographies noires, guérison, espoir, études indigènes

\section{Resumen}

Franz Fanon sostuvo conmovedoramente que el trauma es tanto un acto como un recuerdo de la herida que persigue a los sujetos de la violencia. Abordar las geografías del trauma, y la forma en que se trata el trauma en la disciplina de la geografía, es una cuestión de importancia tanto teórica como práctica para los estudiosos críticos del entorno humano. Sin embargo, las discusiones sobre las geografías desiguales y continuas del trauma y la violencia -en particular, en formas que inscriben a los propios investigadores como agentes dentro de estos paisajes- han sido limitadas entre los ecologistas políticos. Cuando se abordan, estas conversaciones se ven a veces cortocircuitadas por el liberalismo post-racial, la blancura o el eurocentrismo, y la política de respetabilidad académica. Se corre el riesgo de que continúen las lógicas que separan a los "investigadores" de las "comunidades" y que dan más importancia a los compromisos de representación con la justicia que a las prácticas materiales de transformación. En este artículo, analizamos algunas de las implicaciones teóricas y personales para los ecologistas políticos que trabajan con los legados de la desposesión, el desorden, el desplazamiento y la muerte. Nos basamos en un amplio colectivo de estudios sobre el embrujo, la esperanza y las geografías del trauma, así como en nuestro trabajo actual como geógrafos y educadores. En el proceso, construimos un argumento para un enfoque que fomenta conversaciones inquietantes, incómodas y generativas sobre y más allá del trauma. Concluimos con tres sugerencias para abordar de forma más sustantiva las secuelas traumáticas que durante mucho tiempo han estado en el centro de la ecología política.

Palabras clave: cuidados, geografías negras, curación, esperanza, estudios indígenas

\section{Introduction}

.... what are the lineaments of this new narrative? Put differently, how does one rewrite the chronicle of a death foretold and anticipated, as a collective biography of dead subjects, as a counter-history of the human, as the practice of freedom? (Saidiya Hartman 2008: 3)

Political ecology explicates and critiques the systems of power that underlie and structure humanenvironment interactions, particularly those at work in conservation regimes and natural resource governance globally (Blaikie 1985; Peet and Watts 1996; Peluso 1992; West 2006). The fact that nature-society relationships and encounters between marginalized and dominant actors are not only contentious, but also violent and traumatic, has been a preamble to work in political ecology (Robbins 2012; Watts 2015). Because of the particular influence of Antonio Gramsci, Gilles Deleuze, Michel Foucault, David Harvey and Judith 
Butler, political ecologists have also directed much needed attention to how discursive regimes, knowledge systems and seemingly axiomatic explanations of culture and identity are imbricated with power in service of hegemonic political economies, particularly when normative frameworks render violence ordinary (c.f. Agrawal 2005; Blaikie 1985; Ekers and Loftus 2008; Fletcher 2010; Guthman 2012; Mann 2009). The patterns of empirical focus (often the Global South) by researchers in or affiliated within institutions in the Global North (as we all are) has contributed to an outsized influence of scholarly conceptions and problematizations from the Global North. Much of the internal debate about methodologies and research agendas have also tended to be limited to the Anglo-American academy and not always known to the wider readership or political ecologists from the Global South.

These intellectual genealogies are subject to a number of further limitations. These include an oftenuncritical theorization of capitalism that subsumes race into class (c.f Keil 2005; Swyngedouw 1996; Zimmer 2010), the denial of land dispossession, genocide, and epistemic violence as foundational to Western modes of thought (Grosfoguel 2013), and exhortations to a post-human politics that insufficiently addresses the present differentiated struggles for life by exploited groups (Davis et al. 2019; De Leeuw and Hunt 2018; Fernando 2020a; Heynen 2014, 2015; Tuck and Yang 2012). Indeed, violence and trauma are two of the most recurrent and central themes of political ecology, spread across both the titles and scholarly contributions of its canonical texts: Silent violence (Watts 1983), Imposing wilderness (Neumann 1998), Violent environments (Peluso and Watts 2001), and Crimes against nature (Jacoby 2014). Considerable work in political ecology has also emphasized the need to name the functions of capitalism, colonialism, gender, race, able-bodiedness, and other socially constructed axes of differentiation in the reproduction of violent and traumatic nature-society relationships (Bonds and Inwood 2016; Inwood and Bonds 2017; Pulido 2015). Broadly speaking, these analyses conflate power with violence, and theorize this violence as slow, insidious, structural and/or procedural (Davies 2019; Nixon 2011). They seldom trace the visceral, embodied afterlife of the material force of that violence as trauma, or, indeed, the desire for liberation, which may include processes of memorialization and landscape inscription (Tyner, Inwood and Alderman 2014; Davies 2019). Just as problematic is the obscuring of the body in discussions about the production of space and spatial dispossession as emphasis is placed on discourse and symbolic power. At their least reflexive form, such analyses, as Nicholas Blomley argues, "veer dangerously close to a paint-by-numbers formula", where scholars summon, demonstrate, and puncture extant power relations, then reveal modes of resistance and conclude with unspecified, liberatory alternatives that ultimately fail to directly intervene and undo the reproduction of the very same coordinates of power they aim to critique (Blomley 2006: 88, see also Blomley 2003).

We argue that there are further avenues for troubling the ways in which trauma is understood that require critical attunement to differently embodied experiences and their relationships to violence. Our argument is not that all previous examinations of displacement, dispossession, marginalization, and enclosure are uncritical or voyeuristic. Nor are we discounting the work by political ecologists to map the contours of diverse liberation and abolitionist ecologies (Heynen 2016; Peet and Watts 2004). Nevertheless, we take issue with the predominance of interventions that produce totalizing accounts of socio-ecological violence. Following Eve Tuck's call for a moratorium on damage-centered scholarship within settler colonial studies - which "operates, even benevolently, from a theory of change that establishes harm or injury in order to achieve reparation" (2009: 413) - we see a need for a turn to a desire-centered approach to political ecology scholarship, which rather "accounts for the loss and despair, but also the hope, the visions, the wisdom of lived lives and communities" (2009: 417). In recent years, several Indigenous geographers have demonstrated these principles by discussing Indigenous movements for food and water sovereignty (Daigle 2016, 2018), refusals of settler autopsies (Smiles 2018), narrations of ice (Smith 2020) and re-articulations of climate change (Whyte 2017) as sites that nurture relations of accountability, kinship, and Indigenous futurity.

Drawing on Tuck's framework, we propose seriously attending to the ways in which our scholarship and activism can engage trauma, offering more space for radical possibility, accountability, and care. Challenging binary approaches which frame resistance to, and reproduction of, power relations as mutually exclusive processes, we use the term "unsettle" to suggest a confrontation rather than a confession or acknowledgement alone. This acknowledges that resistance to violence can be coextensive with a reproduction of violence and allows us to build a framework that engages a willing refusal of the logic of destruction by centering a praxis 
of interrogation on our own complicity and relationships to the structures we aim to critique. Even among political ecologists, our differentiated experiences of, and relationships to, violence, vulnerability, and trauma inform both our political positionalities and our approaches to research.

This article seeks to encourage and advance the ability of scholars to engage more substantively with the traumatic fallout at the center of political ecology. To do this work, we begin with an origin story that informs the logic of our arguments, when we gathered in 2018 to explore the theoretical and personal implications for political ecologists working within the haunted legacies of dispossession, dislocation, displacement, and death. Following this, we present an overview of the terrain of political ecology and theorize trauma within it, showing that this body of scholarship need not instantiate scenes of despair. We then outline a framework for political ecologies of hope, and offer three sets of propositions/questions as provocations that opens more critically attuned discussions on the legacies of trauma in political ecology. If decolonization, abolition, and emancipation are not metaphors, then there is a responsibility to account for the conditions of embodiment, material relations, and webs of power (De Leeuw and Hunt 2018; Fanon 2007; Gilmore 2017; Heynen and Ybarra 2021; Tuck and Yang 2012). Rather than flattening power relationships, we hope that our attempt to unsettle business as usual will encourage conversations that will carve out new opportunities for relations of liberation within and beyond the spaces of political ecology.

\section{Finding one another}

Judith Butler reminds us that "loss has made a tenuous we of us all" (2004: 20) as we contend with our political lives, our differentiated exposure to threat, violence, and trauma, and to our individual and collective involvement and complicity in re/productive processes of violence. The five authors of this article coalesced into a 'we' while participating in a "Dialogues on the Legacies of Trauma" session at the 2017 Dimensions of Political Ecology Conference (DOPE) at the University of Kentucky. Though our positionalities necessarily differ, our intellectual concerns diverge, and our trajectories vary, our point of alignment is a deeply held ethical concern regarding research and practice on traumatic terrains-past, present, and future. After Avery Gordon, we each "insist on our need to reckon with haunting as a prerequisite for sensuous knowledge and to ponder the paradox of providing a hospitable memory for ghosts out of a concern for justice" (Gordon 1997: 60). This article is the product of collective curiosity about the ongoingness, legacies, and afterlives of dispossession, disruption, displacement and death. It is also evidence of the generative capacity of a desire to understand human-environment relationships beyond a traumatic focus and crystallized parameters of institutional, social, and historical violences.

AM's work has centrally been focused on agrarian change, environmental governance, and development, but interest in ethics of care have shaped how he has examined these issues. Much of his thinking on care and trauma have been motivated by his role as a family eulogist. This article is part of his turn to more centrally addressing commemoration, memory, and care. SV's identity as a Jewish, Russian, second-generation settler in the United States informs her research in Palestine/Israel. Her experiences with somatic therapy, both as a client and as a practitioner in training, have deepened her understanding of how embodied trauma influences her own and others' complicities in interpersonal and state violence, as well as their capacities for subversion and solidarity. Her work explores how post-Soviet and intergenerational trauma shapes migrants' body-minds, informing their participation in settler colonial and white supremacist regimes. DH began research with storytelling and trauma over a decade while collecting stories from Tibetan former political prisoners exiled in Northern India. Though his research focus has shifted, most recently towards climate change and storytelling in rural parts of the U.S., this initial, admittedly clumsy, experience with trauma has influenced his understanding of political ecology scholarship. Contending with personal and political inheritances of genocidal common senses within enduring structures (Wolfe 1999) of settler colonialism, whiteness, and masculinity, CC joined this community in search of more ethical possibilities for being a white, female scholar-practitioner teaching histories of violence to pre-service teachers. Foregrounding the necessity to reckon with personal inheritances, she contributed an auto-ethnography of haunting, examining how violence-masculinity persists in contemporary projects of extinction and erasure; and how her knowledge of herself as [potential] feminist, educator, co-conspirator, are always under threat of invasion. Her work centrally interrogated her own 
relationship to violence and how her pedagogy remains in danger of rendering the triangulations of settler colonialism $<>$ heteropatriarchy $<>$ capitalism indiscernible, despite her desires for justice. BLW is concerned with the entanglement of moral and legal geographies. She is driven by the desire to understand the role of the moral past on present legal decisions and the utility of reparative frameworks and actions among diverse stakeholders. At DOPE, she discussed the points of commensurability between past (anthropological) and speculative (environmental) dispossession, linking her past work with repatriation claims for human remains (ancestors) and cultural objects (belongings) in museums to her then-emerging work on small islands, British and American imperialism, and the ongoing role of compensation in the contemporary lives of diasporic Marshallese and Chagossians.

\section{Re-theorizing trauma in political ecology}

A range of approaches to trauma in postcolonial studies, Black geographies, Indigenous studies, feminist theory, and political geography can inform future engagements with trauma in political ecology, building on the sub-field of emotional political ecology. Political ecologists have called for greater theoretical attention to emotions (Sultana 2015) and healing (Middleton 2010), and scholars working on emotional responses to environmental conflict and ecological catastrophe have called for more explicit theorizations of the political (González-Hidalgo and Zografos 2017, 2019) and the spatial (Walker 2013). Related to the sub-field of emotional geographies (Anderson and Smith 2001; Bondi et al. 2016; Davidson and Milligan 2004; Thrift 2004), emotional political ecology addresses emotions in human-animal interactions (Raento 2016), sustainability and conservation efforts (Croog 2016; Horowitz 2013; Nightingale 2012; Pratt 2012), and resource-related conflicts (Horowitz 2010; Sultana 2015; Wooden 2014). Among the recent work in political ecology that has attended to the body as a site of socio-ecological violence and trauma is Becky Mansfield's and Julie Guthman's (2014) intervention examination of epigenetics. They explore how an analysis of epigenetics - how the environment impacts a body's genetic code - provides further insight into the ways in which inequalities are not only experienced by certain populations, but also how these inequalities become established and persist across generations (see also Guthman 2014). The biopolitical legacies that haunt the way certain bodies are unequally impacted by environmental damage in the present live in direct relation to which kinds of bodies are allowed to exist in the future (Davis et al. 2019; Smith and Vasudevan 2017; Van Sant, et al. 2021). As political ecologists interested in global climate change have also shown, the politics of shapingand recreating-processes and patterns of dispossession make the future a highly contested space (cf. Fairhead, Leach and Scoones 2012; Harris and McCarthy 2020; McCarthy 2015; McCarthy and Thatcher 2017; Paprocki 2018). This scholarship collectively shows that dispossession in the present forecloses the potential for certain bodies to exist or achieve a "livable life" (Butler 2004), and enacts prefigurative forms of violence. Political ecologists must engage in an anticipatory praxis and critically interrogate their own complicity and potential impact in constructing post-traumatic futures.

Like all emotional experiences, trauma is a spatial phenomenon. While we recognize that understandings of trauma are culturally and geographically situated (Andermahr 2016), we also know that many people who have survived trauma and may be haunted by flashbacks, visions, and (dis)associations, might find that oncefamiliar landscapes and spaces (including the body) accumulate new meanings. Together with legacies of scholarship connecting bodies with landscapes in both feminist scholarship (Anzaldúa 1987; Gilmore 2002), environmental justice studies (Bullard 2018; Pellow 2007; Sze 2006; Voyles 2015), and political ecologies of health (Brisbois et al. 2018; King 2009), feminist political ecologists have understood the body as a site for the interaction of political, economic, and ecological forces which co-constitute social identity (Doshi 2017; Gururani 2002; Harris 2015; Sundberg 2017; Truelove 2011), producing the "political ecology of the body" (Hayes-Conroy and Hayes-Conroy 2013). Over the past decade, political ecologists have begun to address the traumatic effects of land seizure, displacement, environmental contamination, and labor exploitation in this way (Dallman et al. 2013; Middleton 2010; Perry 2012; Slocum and Cadieux 2015). While these scholars have begun the work of theorizing and discussing trauma in PE scholarship, we seek to push this project further by finding ways of processing and engaging with trauma more expansively. Crucially, we highlight that Indigenous Studies (Daigle 2016, 2018, 2019; Goeman 2013; Naylor et al. 2018; Tuck and Yang 2012) and emerging Black Geographies scholarship (Davis et al. 2019; Gilmore 2007; McKittrick 2014; Seamster and Purifoy 2021; Van 
Sant et al. 2021; Vasudevan 2021; Wright 2021) already articulate subaltern political ecological analyses that problematize capitalist, carceral, racist, and settler-colonial workings of human-environment governance. Importantly, these literatures clarify pathways for decolonizing political ecologies and antiracist hope-filled, healing, and resilient socio-natures.

Geographers, feminist scholars, and postcolonial theorists have offered numerous approaches to understanding the traumatic effects of settler colonial, heteropatriarchal, and racial capitalist violence. For Fanon (2008), trauma is both the act and memory of an unevenly inflicted wounding. His framework identifies trauma as both a quotidian and a structural phenomenon, individual and collective, inextricable from broader relations of domination, and, as such, distributed in deeply unequal ways within colonial society. Similarly, Berlant (2011) situates trauma as a feature of everyday life, shaping places, people, and emotions in structurally violent, deeply uneven ways. Even though trauma is a key element within colonial relations, De Leeuw (2016) argues that scholars of colonialism have often focused on the traditionally masculinized matters of land and resource rights while failing to address the "tender spaces" of intimate, intergenerational violence and its effects on Indigenous women and children. These tender geographies are fundamentally ecological: because trauma exists at "the hinge point between the physical and the psychic" (Cvetkovich 2003: 50), it connects the materialities of bodies and landscapes to the less-tangible worlds of emotion, meaning, and value. Trauma can also cause individuals and communities to experience changes in the spaces and ecologies of their bodies through lingering toxic or hormonal "body burdens" (Agard-Jones 2016; see also Murphy 2017) and lasting epigenetic transformations (Guthman and Mansfield 2013; Mansfield and Guthman 2014), highlighting the embodiment of affects and emotions as a concern for political ecologists (Doshi 2017). Political ecologists are in a unique position to examine how political and economic forces interface with the embodied ecologies of trauma, such as those inherent in the extractive property relations of colonial displacement and racial capitalism (Heynen 2018).

In spite of - or perhaps because of - its multivalence, trauma is also a category that is refined and produced through a variety of institutional and social forces. Political geographers have attended to the ways in which political, philosophical, academic, medical, and scientific frameworks of trauma delineate what constitutes disaster, and what kind of disaster merits support, effectively "geopoliticizing" phenomena that are already racialized and gendered (Perera 2010). Dominant practices that address trauma as an individualized problem can bypass accounts that identify structural drivers of traumatic experiences (Malkki 2012). While institutional definitions of trauma can shape structural power relations, trauma is also "eminently transactable" (Perera 2010), taken up not only by scientists and political actors, but also, importantly, by displaced and vulnerable people working to make sense of their experiences as outcomes of military and imperial violence (Ehrkamp, Loyd and Secor 2019). As a malleable, contested category, trauma can work to reproduce, rework, or challenge relations of power. By attending to the ways in which people understand and address the traumatic effects of structural violence, political ecologists can challenge the individualization and pathologization of trauma to more fully account for the effects of domination.

Trauma is both emplaced and highly mobile, traversing spatial and temporal categorizations. Traumatic events and their 'flashes' can "fuse the present with the past", "[remapping] time and place onto bodies" while simultaneously destabilizing the idea of a coherent and discrete "self" (Adams-Hutcheson 2017: 105; Gillespie and Lopez 2019). Scholars have also emphasized human relationships with place as potential sites of wounding. When people are displaced through disaster or urban renewal, they may experience "root shock" (Fullilove 2016); at the same time, places themselves can become marked by trauma (Calgaro 2015; Till 2012). However, as McKittrick's work highlights, trauma demarcates space differently for different people-a slave burial ground can be a site of "community mourning" for some and a source of "scientific excitement" for others (2006: 1; see also McKittrick 2014). Trauma is embedded in particular times and places and for particular people; at the same time, it is contagious, spreading through relations of proximity (Coddington 2017).

Trauma's mobility also troubles colonial, capitalist, and hetero-patriarchal understandings of space-time. By challenging dominant orderings of time and space, engagements with trauma can disrupt geopolitical demarcations of territory and historical demarcations of past, present, and future (Cvetkovich 2003). Trauma crosses national borders through communities of migrants, refugees, and captive people, and is passed down intergenerationally in ways that resist forgetting. Scholarship on the "geopolitics of trauma" advocates for a 
relational, rather than individualizing, approach to trauma that places it within a broader context of structural violence (Loyd et al. 2018). This carries significant implications for how political ecologists relate to their research. Traumatic narratives which disrupt the ontologies of linear time or cartesian space (including mindbody and body-land dualisms) can produce richer engagements with political ecology that acknowledge the time- and space-warping impacts of violence; particularly when we recognize the atmospheric nature of violence (Fanon 1963). Never "over and done with" (Gordon 1997; Morrison 2004), trauma can offer a framework for analyzing the multigenerational and intercontinental effects of phenomena such as colonization, genocide, diaspora, and slavery that makes possible interrogations of the afterlives of violence. Trauma is relational, producing collectivities and creating openings for ongoing life. Emerging in the context of survival, it is neither static nor predictable. Moving between people as a "relational topology" (Ehrkamp, Loyd and Secor 2019: 126), it makes itself known through "affective eruptions" (Mountz 2017) which connect colonial past to present, exposing histories of structural violence and domination. Trauma also creates what Cvetkovich (2003) terms "public cultures"; or cultural production and affects constituted by the public practices of responding to trauma. Because public cultures of trauma emerge from negotiations, a kind of collective therapeutic and political response to trauma and its meanings, they can both generate and transform communities around experiences of violence (see also Coddington and Micieli-Voutsinas 2017).

Noah De Lissovoy (2018) theorizes the concept of "violation", which attends to the persistent and willful motivation of domination alongside the persistence of survival and refusal, as the evidence of human beings in struggle. The point is that the processes of violation and survival are co-extensive and simultaneous. De Lissavoy, therefore, focuses on affirming the human before and beyond injury and violence. In this way it is a refusal of liberal humanisms (and some critical perspectives) that suggest our humanity can only be grasped through a process of consciousness. McKittrick (2006; 2014) likewise highlights the continuity of Black peoples' survival strategies within and beyond the plantation, including practices of creolization, blues, maroonage, and revolution. Drawing on Wynter's framing of plot and plantation, McKittrick emphasizes the emplaced nature of trauma. She highlights Black peoples' approaches to place-making, negotiations, and modes of being that exceed categories of "oppression" and "resistance." Following Wynter and McKittrick, an understanding of how collective life emerges in the context of different woundings as a site of variegated affinity and solidarity, may offer a stronger framework for social and political engagement that heals and sustains.

Trauma can also challenge the traditional subject-object relationship between the researcher and the object/site of research. Working in trauma landscapes can affect researchers intellectually and somatically, reshaping their relationships to place (Calgaro 2015) and to themselves, binding the traumas they encounter in fieldwork to existing traumas in a compounding process (Coddington 2017). Building on feminist geography, which has long challenged the distinction between the researcher and "the field" (Hyndman 2001; Katz 2018; 1994; Nast 1994; Sharp and Dowler 2011; Sundberg 2003), engaging trauma "reminds us that there is literally no place 'outside' of research - and conversely, no research that is 'beyond' the body" (Coddington and MicieliVoutsinas 2017). For those of us who are trauma survivors, and/or are traumatized through the course of our research, trauma, grief, and other emotional geographies can enroll us as participants rather than as estranged or objective observers (Mitchell-Eaton 2019). Rather than spectacularizing the horrors of violence (Hartman 1997; McKittrick 2014) or, conversely, attempting to palliate difficult emotions (Willis 2009), researchers can respond to trauma by bearing witness to harm, recognizing the affective entanglements of trauma (Ahmed 2004), excavating and amplifying stories of healing by "speaking truth to pain" (Gillespie and Lopez 2019: 193). These stories of healing might take the shape of "memory-work", drawing on the past as a resource to resolve historical injustices (Till 2012) and informing decolonizing activism (González-Hidalgo and Zografos 2017; Middleton 2010). Researchers can also promote accountability (Russo 2018), advocating for the decolonial, abolitionist, or redistributive, changes that can help support healing. Our responses to trauma may, at times, reproduce harm (Middleton 2010), particularly when research is not necessary or welcome (Tuck and Yang 2014; Goodman et al. 2018). At other times, they can support resistance and survival. 


\section{Toward political ecologies of hope}

Before proceeding, we want to qualify our conceptualization of 'hope' as not being a matter of things being prescriptively 'better', and therefore based on previous notions of 'good', but as a matter of imagining things otherwise. So far, we have argued that violence and trauma are critically important themes in political ecological scholarship. However, we have also articulated a way to think differently about violence and trauma, considering the ways in which centering these elements potentially orient research questions and methods towards more violence and trauma, determine relationships among and between the people and places we research, and, at worst, recapitulate much of the same trauma we intend to critique by overlooking the ways in which violence is metabolized. We have argued for a desire-centered approach to research, one that acknowledges violence and trauma but that also seeks to affirm lived experience and wisdom among participants. In other words, we are interested in turning more explicitly towards a hopeful political ecology.

Gramsci is often cited in political ecology for his conceptualization of hegemony (Mann 2009; Moore 2005); however, he is rarely, if ever, cited for his conceptualization of hope. Writing as a political prisoner from his cell, he envisioned the prospects of a new world order: "the beginnings of a new world, rough and jagged as they always are, are better than the passing away of the world in its death-throes and the swan-song that it produces." Hope is jagged; it is difficult. Yet, it is necessary for envisioning a world otherwise. Writing about finding hope in 'blasted landscapes' - spaces of capitalist ruin - Kirksey et al. (2013: 230), invoking Derrida, argue that hope is not always emancipatory. Being hopeful does not necessarily mean having hope in something that is prescriptively better. Rather, being hopeful means having hope that things will be different, otherwise.

Considering multiple and ongoing crises, including climate change, it is easy to sink into hopelessness about what is possible. Hopelessness can result in a kind of future-oriented dispossession, where the 'possession' of possibility is foreclosed or delimited. We see this concern present in work like Kyle Whyte's, where he argues that "narratives of crises, dystopia, and apocalypse obscure and erase ongoing oppression against Indigenous peoples and other groups", in large part because these persons are often rendered as historical beings by the non-indigenous (2018: 11 [emphasis added]). As Whyte (2018) also reminds us, several worlds have already ended as colonialism, racism, and capitalism wrought transformations in socio-ecological systems, and, yet, just as many have endured through subaltern resistance and place-making. Similarly, Jose Estaban Muñoz (2009), who is writing in memory of an entire generation of queer folks almost lost to the AIDS crisis, articulates hope as potential, as something that is always 'then' and 'there', pushing our conceptions of the 'here' and 'now' into spaces unfathomable. This version of hope - one that persists in the face of adversity, pushing the boundaries of potential and possibility - is central to the hope we aim to champion in our intervention into political ecological scholarship.

In her articulation of what hope might look like methodologically, Saidiya Hartman argues for engagements with archives that shift historicization from the registers of violence and subjectification. For Hartman this entails "listening for the unsaid, translating misconstrued words, and refashioning disfigured lives...[towards]...redressing the violence that produced numbers, ciphers, and fragments of discourse, which is as close as we come to a biography of the captive and the enslaved" (2008: 3). This mode of reading between the lines can recuperate the lives denied in the archives, thereby working to overcome the limitations of what the archives make knowable (McKittrick 2014). By exhuming the complex lives buried beneath preponderant accounts of violence, scholars can help create space in their accounts for subjects who exceed the confines of statistical enumeration and corporeal brutalization. "The dream is to liberate them from the obscene descriptions that first introduced them to us" (Hartman 2008: 6).

In a similar vein, Clyde Woods reminds us that the "The same tools that symbolize hope in the hands of the surgeon symbolize necrophilia in the hands of the coroner" (2000: 63). More than this, Woods asks, "Have we become academic coroners? Have the tools of theory, method, instruction, and social responsibility become so rusted that they can only be used for autopsies? Does our research in any way reflect the experiences, viewpoints, and needs of the residents of these dying communities? On the other hand, is the patient really dead? What role are scholars playing in this social triage?" (ibid). What Woods calls for with these questions and in his broader work, is a consideration of the ways communities contest the material and economic forms of disinvestment (Woods 1998, 2017). Rather than accepting 'the premature' reports of the death of African 
American communities, Woods calls attention to the counter-hegemonic cultural practices and social movements of African American communities. The exposure to violence these communities face and the ongoing trauma of structural racism, he shows, is counteracted by a praxis of hope which finds sonic expression in the blues musical tradition. Woods foregrounds the violent practices of white supremacy and the traumatic effects of state-sanctioned and -enacted racially uneven development policies but emphasizes the Black social movements that pursue new possibilities for Black embodiment and regional development. Similarly, Christina Sharpe (2016) articulates a vision of wake work, an approach and practice of work that combines acts of mourning, commemorating, and celebrating lost life. Sharpe's approach insists on more than an appeal for justice for the dead and dying. To be sure, these things are important. However, Sharpe is centrally concerned with confronting the ways that racial violence persists structurally, the afterlives of slavery. Wake work follows the daily ways through which blackness as a conditioned form of being struggles against death and points toward how critical discursive redacting and annotating can serve to make Black life visible. In these ways, Sharpe's work calls attention to Black embodiment as not just a site of violence and trauma, but enactment of critique.

What we read from these scholars is a call from the work of pathology and autopsy to the work of eulogizing and obituarizing. We do not see this as meaning simply writing more encomiums, rather we are thinking about the critical modalities of narrating life and struggle (McKittrick 2013, 2014). That is to say, from the diagnosis of the cause of death or the technologies and rationalities that produce death, towards what enables life and resistance. With this in mind, we think through the eulogies and obituaries, less as written documents and more as analytic/conceptual devices for positive grieving and post-trauma hope. Our conception ties into long-time anarchist organizer, Cindy Milstein's (2017), writing on 'rebellious mourning', which effectively argues that the means of grieving, of processing trauma, be taken back into collective control in the face of ongoing crisis and death. Conceptually, we see obituaries and eulogies as devices offering an analytic for thinking with care and storying interdependence and mutuality with the dead (Puig de la Bellacasa 2012; van Dooren 2014). An obituary identifies the dead, announces the death, and names the cause of death; the eulogy tells the story of the dead, recounting the multiplicity of social relations. Critically, obituraization/eulogization can bring the dead into geography and serve as a corrective to the usual non-affective view/connection to death. A pathology or autopsy seems to only cut the dead up (Mol 2002). Eulogizing and obituarizing, as intentional practices, call towards a grappling with violence and trauma in order to understand the situation of the dead and the living within the death dealing workings of power, life sustaining kinship relationships, physical geographies and sites of social reproduction, as well as the spectral past and futures.

To be sure, much of some of this work which we have discussed in this section is sociological, or emerges from cultural studies, and critical theory, but can, should, and has been drawn into geography broadly, and increasingly into political ecology in particular. We see additional integration of this work offer constructive insights for devising a framework for addressing ecological grief and mourning, and political ecologies of trauma. Returning to the question of political ecology of hope and the future, we want to signal a number of political ecological works that are wary of violent, future-oriented narratives, and offer more hopeful theorizations instead (Fernando 2020b; Robbins 2020; Lawhon et al. 2021; Paulson 2021). Though the realities of the apparent Anthropocene are largely dire, Buck (2015) asks us to consider the possibilities of a charming Anthropocene. Rather than centering violence, she uses the Anthropocene as a pivot to acknowledge but also to dismantle the violence that resulted in this moment, and to reconsider the potential of a future-otherwise. She also asks us to do the same when considering a world that may exist 'after geoengineering' to solve the climate crisis (Buck 2019). Similarly, Collard et al. (2015), mindful of historical conservation practices and the wealth of political ecological criticism levied against them, ask us to consider the prospect of abundance. Rather than focusing squarely on the violence associated with conservation practices, and the scarcity that is so often associated with them, they ask us to think more broadly about what kinds of futures are possible, and, importantly, who and what are able to live in them (McKittrick 2013). These works serve as critical interventions, highlighting ways in which political ecological work can be used to envision more hopeful, less tragic futures. They remind us and point towards directions for doing our work differently. 


\section{New ethical engagements: relationality, positionality, potentiality}

Discussions among political ecologists grappling with the uneven geographies of trauma and violence particularly in ways that enroll the researchers themselves as agents within these landscapes - have been limited. When broached, these conversations can be short-circuited by "post"-racial liberalism (Bonilla-Silva 2003), white fragility (DiAngelo 2011), and academic respectability politics (Harris 2014) - contemporary manifestations of the American academy's foundational white supremacy (Wilder 2013). A concomitant attention to the personal, material, and embodied dimensions of life has been largely excluded from the debates about awful political ecologies.

The reflexive turn in political ecology brought on by feminist political ecologists and post-structural political ecologists asks us to consider how researchers ask their questions and situate themselves (see for example the 2018 special issue on 'Affirmative Political Ecology' in Nordia Geographical Publications, edited by Alhojärvi and Sirviö [2018], and Sundberg 2015). However, we researchers must also ask what these questions mean with regard to the trauma and violence we wish to interrogate, and reflect on our (in)capacity to address the traumatic fallout that we encounter or evoke. This is particularly important since most political ecologists are not trained psychologists. Moreover, even if we were, our positionality needs to be continuously examined. We must ask: What are the implications of reproducing careers as scholars of other people's trauma, violent encounters, displacement, and dispossession? Even when we focus attention on quests for abolition and emancipation, the ways we participate in those struggles and build careers must be interrogated (Gilmore 2017; Heynen and Ybarra 2021). These "implications" cannot merely be thought about as concerns to reflect on 'afterthe-fact' as part of our work. Further, it is our hope that the questions and ideas raised by this article spark new ways of conducting research with people as opposed to research about them.

We see an ethical necessity to confront ourselves and historically informed positions within the longer life of domination and destruction as we make choices to engage in our work. We believe that this kind of transformation requires the researcher to claim participation within the landscape of what they work on. To this end, we propose three broad invitations for future political ecology scholarship. Before outlining these invitations, we offer the following questions as broad provocations:

- How do our various identities—race, gender, class, ability, embodiment, nationality, sexuality-shape our selection of research topics?

- To what extent is our ability to perform research in academic institutions enabled by intergenerational wealth and social capital, and by historic and ongoing exploitation of colonized people? In other words, what sorts of violence are we inescapably akin to?

- What sorts of violence do we live in direct and embodied relations with, and how has it brought us to conducting research within the academy - or constrained our ability to do so?

- What is at stake, and for whom, when we do research as accomplices rather than allies or outside observers (Indigenous Action Media 2014)?

- To what extent are those of us with structural advantages willing to leverage, or lay down, these advantages as part of a more ethical commitment to liberation that struggles "simultaneously with, against, and beyond the university" (Meyerhoff and Noterman 2019)?

While we understand that the project of creating a more accountable and reflexive field is a process rather than an outcome, we hope that these provocations and our suggestions can work as guideposts for more honest, reflective, and transformative engagements with the traumas of dispossession, disruption, displacement and death.

\section{Decenter dominant narratives and modes of narration}

We recognize the necessity to decenter Western onto-epistemologies and support alternative modes of thinking, being, and conducting scholarship. While understanding the heterogeneity of these communities, we particularly encourage foregrounding theorizations and practices of Black and Indigenous scholars, scholars of 
color, non-Western scholars, and those operating from within the intersections of multiple marginalized identities whose knowledge practices have historically been excluded from, and delegitimized within, academic institutions (including those challenging internalized oppression within marginalized communities). By understanding that the Western academy has historically operated through a material and intellectual process of colonial plunder, we can challenge its historically extractive modes of operation, not as a move to settler innocence (Daigle 2019; Tuck and Yang 2012; Wolfe 1999, 2006), but as a praxis of care and accountability that is guided by a desire towards more ethically rooted relations. This means unsettling dominant Western analytical and philosophical tools, opting instead to be led by the methodologies of communities most affected by settler colonialism and racial capitalism, and importantly to engage in citational practices that reflect the scholars whose work guides our theorizations and desire for unsettling dominant frameworks (Batterbury 2017).

\section{Acknowledge, interrogate, and leverage the resources and opportunities afforded by our social positions}

We take seriously the question of whether ethical participation in the communities we are learning alongside is possible, given our positionalities and the material realities of socio-historical structures of violence. Our identities are foundational to the work that we produce as academics; put differently, "to speak is to speak from a place on the map" (Roy 2016: 201). Moreover, decolonial praxis "insists upon accountability from academics as embodied subjects, in their writing and in their practice" (Ramírez in Naylor et al. 2018). As political ecologists, we come from different backgrounds, so we offer a series of questions rather than prescriptions. Following Tuck and Yang's (2012) assertion that decolonization requires the return of land to Indigenous people rather than simply a discursive move, we invite political ecologists to consider how we can participate materially in the redistribution of resources as an act of care (see also, Derickson and Routledge 2015). We anticipate that for some this might mean not participating in the academy, while for others it might mean figuring out ways of participating in the academy that makes space for others. Michelle Daigle cautions, "[w]ithout embodying such radical and transformative accountabilities-as necessarily unsettling, potentially discomforting and contentious as they are-geographers risk reproducing a prevalent trope and buzzword in academia, and the very structures of settler colonialism and white supremacy that we claim to dismantle in our calls for decolonization" (Daigle in Naylor et al. 2018: 203).

\section{Anticipate and engage personal and collective traumas}

Conducting research with marginalized communities without engaging people's emotional realities can work to reproduce the Cartesian cuts of colonial knowledge production and violation, severing bodies from minds and souls. Moreover, dynamics of emotional and material reciprocity must take center stage within research, particularly across differentiated landscapes of power. If we enter our research with the intention of attuning to the lived realities of the people with whom we work, then we can work to position ourselves as part of a relational field that is defined by interdependency and accountability rather than along a gradient of unidirectional knowledge extraction. Often, such 'positioning' has been limited to discussions or acknowledgements of embodied differences. In such instances, how people come to matter hierarchically based on systems of social differentiation, and how such systems work are discursively reproduced, escape serious interrogation. This leaves uncritiqued the politics and limits of recognition and the implications for addressing violence targeted toward the unrecognized or discounted. Instead, what we are suggesting is grappling with questions of ethics and praxis in regard to complicity and re/production of the forms of violence that we aim to critique. Researchers must "pay it forward" (Ybarra 2014) through a number of modalities which both engage and honor the traumatic accumulations and material needs of the communities that they/we work alongside. Necessarily, this requires a deep listening and attunement to the particularities of how "trauma" works for individuals and communities we live in relation to. It also requires attention to our own frameworks that guide our recognition and identification of "trauma." We must remain committed to interrogating all that we think we know, and the nuances that are a part of studying, naming, and moving beyond trauma-centered work in political ecology. 


\section{Conclusion}

As the world continues to confront the realities of a still-raging pandemic, we can perceive the effects of the legacies of trauma in the differentiated mortality and vaccination rates. This perception is of course based on awareness of the ways in which vulnerability to threat, dispossession, and disposability are unevenly distributed and historically rooted in structural inequalities. We can recognize the continued accumulations of politically induced trauma in: hospitals where there are limited resources due to supply chain shortages; in BIPOC communities that were already rendered vulnerable under regimes of racial capitalism being devastated by the pandemic; and in the countless losses and permanent ruptures created by avoidable deaths (Fernando 2020a; Leach et al. 2021; Liebman et al. 2020). Violence is also actively reproduced by elite actors, glossed over, and amplified through misinformation campaigns that are rendered legitimate by repetition. The outcomes of such legitimizing include the crystallization of regimes of power and the manufacture of ideological cohesion. Global communities are effectively rendered disposable as they are denied access to COVID-19 vaccines. And yet, every day as unprecedented traumas - collective and individual - accumulate, we find ourselves aspiring to keep up with "business as usual."

Capitalism's death drive has never quite demanded attention to care in such a critical way as it does now (Fernando 2020b; Liebman et al. 2020; Lopez and Neely 2021). As researchers and educators, we - alongside the rest of society - have had to reevaluate the nature of our work, and think deeply and intentionally about the communities in which we live and build relationships. As we think through the politics of engagement with trauma, of its enduring effects, of its unaccounted-for accumulations and the legacies and ghosts that will haunt us into a desired future, it is necessary that we consider the ethics of research. It is necessary that we attune to the realities of 'right now' and learn to ask better questions for the sake of ourselves, our students, and the people with whom we collaborate and whose worlds we are invited to inhabit.

The claim we make in this article is a simple one, though one with very visceral portent. Much of the work in political ecology is concerned with the unsettling geographies of displacement, disruption, dislocation, and death. Yet, the normalization of these geographies as the stuff of political ecology can often leave the ongoing processes and outcomes of trauma and violence - traces left on bodies, imprinted in landscapes, and enmeshed with the research we do - untroubled. These traces have the capacity to both hinder and inspire the remaking of worlds, when we consider that while trauma may be an inevitable companion of social and ecological domination, a framework of despair and damage are insufficient for imagining and enacting an ethical future. With this in mind, we invite further theorizations of trauma that seek out the possibilities of a more transformative political ecology specifically, but also more transformative approaches to nature-society scholarship, political geography, studies of mobilities, and environmental sociology (etc.) where trauma is a theme. It is ethically imperative to recognize that complicity - from the position of researcher - may (re)produce some aspects of the trauma and violence we aim to critique. This requires attention to ourselves as subjects and to interrogating, deeply, the "selves" that may have been handed over to us within multi-sited and ongoing frameworks of domination. Our suggestion has been that we take steps towards new, affective relationships that allow us to reweave the landscapes of damage, desire, and resistance within political ecology. We must do this in collaboration and partnership with the communities with which we work, work that requires care if we are to conduct research that makes claims of "liberation" or "justice."

\section{References}

Adams-Hutcheson, G. 2017. Spatialising skin: Pushing the boundaries of trauma geographies. Emotion, Space and Society 24: 105-112.

Agard-Jones, V. 2016. Episode 35. Cultures of Energy. http://culturesofenergy.com/ep-35-vanessa-agardjones/

Agrawal, A. and J. Bauer. 2005. Environmentality: Technologies of government and the making of subjects. Duke University Press.

Ahmed, S. 2004. Collective feelings: Or, the impressions left by others. Theory, Culture \& Society 21(2): 2542. 
Alhojärvi, T., \& Sirviö, H. (2018). Affirming political ecology: seeds, hatchets and situated entanglements. Nordia Geographical Publications, 47(5): 1-6.

Andermahr, S. (ed.). 2016. Decolonizing trauma studies: Trauma and postcolonialism. MDPI.

Anderson, K. and S.J. Smith. 2001. Editorial: Emotional geographies. Transactions of the Institute of British Geographers 26(1): 7-10.

Anzaldúa, G. 1987. Borderlands/La Frontera. Aunt Lute.

Batterbury, S.P.J. 2017. Socially just publishing: Implications for geographers and their journals. Fennia: International Journal of Geography 195(2): 175-181.

Berlant, L. 2011. Cruel Optimism. Duke University Press.

Blaikie, P.M. 1985. The political economy of soil erosion in developing countries. Longman.

Blomley, N. 2003. Law, property, and the geography of violence: The frontier, the survey, and the grid. Annals of the Association of American Geographers 93(1): 121-141.

Blomley, N. 2006. Uncritical critical geography? Progress in Human Geography 30(1): 87-94.

Bondi, L., J. Davidson, and M. Smith. 2016. Introduction: Geography's 'emotional turn.' In Davidson, J., L. Bondi and M. Smith (eds.). Emotional geographies. Routledge.

Bonds, A. and J. Inwood. 2016. Beyond white privilege: Geographies of white supremacy and settler colonialism. Progress in Human Geography 40(6): 715-733.

Bonilla-Silva, E. 2017. Racism without racists: Color-blind racism and the persistence of racial inequality in America. Rowman \& Littlefield.

Brisbois, B.W., L. Harris, and J.M. Spiegel. 2018. Political ecologies of global health: Pesticide exposure in Southwestern Ecuador's Banana Industry. Antipode 50(1): 61-81.

Buck, H. J. 2015. On the possibilities of a charming Anthropocene. Annals of the American Association of Geographers. 105(2): 369-377.

Buck, H. J. 2019. After Geoengineering: Climate tragedy, repair, and restoration. Verso.

Bullard, R. D. 2018. Dumping in Dixie: Race, class, and environmental quality, Third Edition. Routledge.

Butler, J. 2004. Precarious life: The powers of mourning and violence. Verso.

Calgaro, E. 2015. If you are vulnerable and you know it raise your hand: Experiences from working in posttsunami Thailand. Emotion, Space and Society 17: 45-54.

Chakrabarty, D. 2009. Provincializing Europe: Postcolonial thought and historical difference. New Ed. Princeton University Press.

Coddington, K. 2017. Contagious trauma: Reframing the spatial mobility of trauma within advocacy work. Emotion, Space and Society 24: 66-73.

Coddington, K., \& J. Micieli-Voutsinas. 2017. On trauma, geography, and mobility: Towards geographies of trauma. Emotion, Space and Society 24: 52-56.

Collard, R., J. Dempsey, and J. Sundberg. 2015. A manifesto for abundant futures. Annals of the American Association of Geographers. 105(2): 322-330.

Croog, R. 2016. Campus sustainability at the edges: Emotions, relations, and bio-cultural connections. Geoforum 74: 108-116.

Cvetkovich, E. 2003. An archive of feelings. Duke University Press.

Daigle, M. 2016. Awawanenitakik: The spatial politics of recognition and relational geographies of Indigenous self-determination. The Canadian Geographer/Le Géographe canadien 60(2): 259-269.

Daigle, M. 2018. Resurging through Kishiichiwan: The spatial politics of Indigenous water relations. Decolonization: Indigeneity, Education \& Society 7(1): 159-172.

Daigle, M. 2019. The spectacle of reconciliation: On (the) unsettling responsibilities to Indigenous peoples in the academy. Environment and Planning D: Society and Space 37(4): 703-721.

Dallman, S., M. Ngo, P. Laris, and D. Thien. 2013. Political ecology of emotion and sacred space: The Winnemem Wintu struggles with California water policy. Emotion, Space and Society 6: 33-43. 
Davidson, J., and C. Milligan. 2004. Embodying emotion, sensing space: Introducing emotional geographies. Social \& Cultural Geography 5: 523-532.

Davies, T. 2019. Slow violence and toxic geographies: 'Out of sight' to whom? Environment and Planning C: Politics and Space. 0: 1-15.

Davis, J., A.A. Moulton, L. Van Sant, and B. Williams. 2019. Anthropocene, capitalocene,... plantationocene? A manifesto for ecological justice in an age of global crises. Geography Compass 13(5): e12438.

de la Bellacasa, M.P. 2012. 'Nothing comes without its world': thinking with care. The Sociological Review 60(2): 197-216.

De Leeuw, S. 2016. Tender grounds: Intimate visceral violence and British Columbia's colonial geographies. Political Geography 52: 14-23.

De Leeuw, S., and S. Hunt. 2018. Unsettling decolonizing geographies. Geography Compass 12(7): e12376

De Lissovoy, N. 2018. Value and violation: Toward a decolonial analytic of capital. Radical Philosophy Review 21(2): 249-270.

Derickson, K.D. \& P. Routledge. 2015. Resourcing scholar-activism: collaboration, transformation, and the production of knowledge. The Professional Geographer, 67(1): 1-7.

DiAngelo, R. 2011. White fragility. The International Journal of Critical Pedagogy 3(3).

Doshi, S. 2017. Embodied urban political ecology: Five propositions. Area 49(1): 125-128.

Ehrkamp, P., J.M. Loyd, and A. Secor. 2019. Embodiment and memory in the geopolitics of trauma. In K. Mitchell, R. Jones and J.L. Fluri (eds.). Handbook on Critical Geographies of Migration. Edward Elgar.

Ekers, M. and A. Loftus. 2008. The power of water: developing dialogues between Foucault and Gramsci. Environment and planning D: Society and Space 26(4): 698-718.

Fairhead, J., M. Leach. and I. Scoones (2012). Green grabbing: a new appropriation of nature? Journal of Peasant Studies 39(2): 237-261.

Fanon, F. 2007 [1961]. The wretched of the earth. Grove/Atlantic.

Fanon, F. 2008 [1952]. Black skin, white masks. Grove Press.

Federici, S. 2004. Caliban and the Witch. Autonomedia.

Fernando, J.L. 2020a. The Virocene Epoch: The vulnerability nexus of viruses, capitalism and racism. Journal of Political Ecology 27(1): 635-684.

Fernando, J.L. 2020b. From the Virocene to the Lovecene epoch: Multispecies justice as critical praxis for Virocene disruptions and vulnerabilities. Journal of Political Ecology 27(1): 685-731.

Fletcher, R. 2010. Neoliberal environmentality: towards a poststructuralist political ecology of the conservation debate. Conservation and Society 8(3): 171-181.

Fullilove, M.T. 2016. Root shock: How tearing up city neighborhoods hurts America, and what we can do about it. New Village Press.

Gillespie, K. and P.J. Lopez. 2019. Vulnerable witness: The politics of grief in the Field. University of California Press.

Gilmore, R.W. 2002. Fatal couplings of power and difference: Notes on racism and geography. Professional Geographer 54(1): 15-24.

Gilmore R.W. 2007. Golden Gulag: Prisons, surplus, crisis, and opposition in globalizing California. University of California Press.

Gilmore R.W. 2017. Abolition geography and the problem of innocence. In G.T. Johnson and A. Lubin (eds.). Futures of Black radicalism. Verso. Pp. 225-240.

Goeman, M. 2013. Mark my words: Native women mapping our nations. University of Minnesota Press.

González-Hidalgo, M. and C. Zografos. 2017. How sovereignty claims and "negative" emotions influence the process of subject-making: Evidence from a case of conflict over tree plantations from Southern Chile. Geoforum 78: 61-73. 
González-Hidalgo, M., and C. Zografos. 2019. Emotions, power, and environmental conflict: Expanding the 'emotional turn' in political ecology. Progress in Human Geography 44(2): 235-255.

Goodman, A., R. Morgan, R. Kuehlke, S. Kastor, K. Fleming and J. Boyd. 2018. "We've been researched to death": Exploring the research experiences of urban Indigenous peoples in Vancouver, Canada. International Indigenous Policy Journal 9(2).

Gordon, A. 1997. Ghostly matters: Haunting and the sociological imagination. University of Minnesota Press.

Grosfoguel, R. 2013. The structure of knowledge in westernized universities: Epistemic racism/sexism and the four genocides/epistemicides of the long 16th century. Human Architecture: Journal of the Sociology of Self-Knowledge 11(1): 8.

Gururani, S. 2002. Forests of pleasure and pain: Gendered practices of labor and livelihood in the forests of the Kumaon Himalayas, India. Gender, Place, and Culture 9(3): 229-243.

Guthman, J. 2014. Doing justice to bodies? Reflections on food justice, race, and biology. Antipode 46(5): 1153-1171.

Guthman, J. and B. Mansfield. 2013. The implications of environmental epigenetics: A new direction for geographic inquiry on health, space, and nature-society relations. Progress in Human Geography 37(4): 486-504.

Guthman, J. 2012. Opening up the black box of the body in geographical obesity research: Toward a critical political ecology of fat. Annals of the Association of American Geographers 102(5): 951-957.

Harcourt, W. and I.L. Nelson. 2015. Practising feminist political ecologies: Moving beyond the 'green economy'. Zed.

Harris, D.M. and J. McCarthy. 2020. Revisiting power and powerlessness: Speculating on West Virginia's energy future and the externalities of the socioecological fix. Environment and Planning E 0:1-25. https://doi.org/10.1177/2514848620935751.

Harris, F.C. 2014. The rise of respectability politics. Dissent 61(1): 33-37.

Harris, L. 2015. Hegemonic waters and rethinking natures otherwise. In W. Harcourt and I.L. Nelson (eds.). Practising feminist political ecologies: Moving beyond the 'green economy'. Zed.

Hartman, S. 1997. Scenes of subjection: Terror, slavery, and self-making in Nineteenth-century America. Oxford University Press.

Hartman, S. 2008. Venus in two acts. Small Axe 12(2): 1-14.

Hayes-Conroy, J., and A. Hayes-Conroy. 2013. Veggies and visceralities: A political ecology of food and feeling. Emotion, Space and Society 6: 81-90.

Heynen, N. 2014. Urban political ecology I: The urban century. Progress in Human Geography 38(4): 598604.

Heynen, N. 2016. Urban political ecology II: The abolitionist century. Progress in Human Geography 40(6): 839-845.

Heynen, N. 2018. Urban political ecology III: The feminist and queer century. Progress in Human Geography 42(3): 446-452.

Heynen, N. and M. Ybarra. 2021. On abolition ecologies and making "freedom as a place." Antipode, 53(1): 21-35.

Horowitz, L. 2010. "Twenty years is yesterday": Science, multinational mining, and the political ecology of trust in New Caledonia. Geoforum 41(4): 617-626.

Horowitz, L. 2013. Toward empathic agonism: Conflicting vulnerabilities in urban wetland governance. Environment and Planning A 45: 2344-2361.

Hyndman, J. 2001. The Field as Here and Now, Not There and Then. Geographical Review 91(1/2): $262-272$.

Indigenous Action Media. 2014. Accomplices not allies: Abolishing the ally industrial complex. Accessed February 3, 2019. Available at: https://www.indigenousaction.org/accomplices-not-allies-abolishingthe-ally-industrial-complex/ 
Inwood, J. F., and A. Bonds. 2017. Property and whiteness: The Oregon standoff and the contradictions of the US settler state. Space and Polity 21(3): 253-268.

Jacoby, K. 2014. Crimes against nature: Squatters, poachers, thieves, and the hidden history of American conservation. University of California Press.

Katz, C. 1994. Playing the Field: Questions of fieldwork in geography. Professional Geographer 46: 67-72.

Katz, C. 2018. The Expeditions of Conjurers: Ethnography, Power, and Pretense. Feminist Dilemmas in Fieldwork. Routledge.

Keil, R., 2005. Progress report: urban political ecology. Urban Geography 26(7): 640-651.

King, B. 2009. Political ecologies of health. Progress in Human Geography 34(1): 38-55.

Kirksey, S.E., N. Shapiro, and M. Brodine. 2013. Hope in blasted landscapes. Social Science Information 52(2): 228-256.

Lawhon, M., M. Henderson, and T. McCreary. 2021. Neither more nor less, but enough: Towards a modest political ecology of the future. Political Geography. 88: 102376. https://doi.org/10.1016/j.polgeo.2021.102376.

Leach, M., H. MacGregor, I. Scoones and A. Wilkinson. 2021. Post-pandemic transformations: How and why COVID-19 requires us to rethink development. World Development 138: 105233. 10.1016/j.worlddev.2020.105233

Liebman, A., Rhiney, K., \& R. Wallace. 2020. To die a thousand deaths: COVID-19, racial capitalism, and anti-Black violence. Human Geography 13(3): 331-335.

Lopez, P. J., \& A,H. Neely. 2021. Fundamentally uncaring: The differential multi-scalar impacts of COVID19 in the US. Social Science \& Medicine 272: 113707.

Loyd, J.M., P. Ehrkamp and A.J. Secor. 2018. A geopolitics of trauma: Refugee administration and protracted uncertainty in Turkey. Transactions of the Institute of British Geographers 43(3): 377-389.

Malkki, L. 2012. Purity and Exile: Violence, memory, and national cosmology among Hutu refugees in Tanzania. University of Chicago Press.

Mann, G. 2009. Should political ecology be Marxist? A case for Gramsci's historical materialism. Geoforum 40(3): 335-344.

Mansfield, B. and J. Guthman. 2014. Epigenetic life: Biological plasticity, abnormality, and new configurations of race and reproduction. Cultural Geographies 22(1): 3-20.

McCarthy, J. 2015. A socioecological fix to capitalist crisis and climate change? The possibilities and limits of renewable energy. Environment and Planning A: Economy and Space 47(12): 2485-2502.

McCarthy, J. and J. Thatcher. 2017. Visualizing new political ecologies: A critical data studies analysis of the World Bank's renewable energy resource mapping initiative. Geoforum 102: 242-254.

McKittrick, K. 2006. Demonic grounds: Black women and the cartographies of struggle. University of Minnesota Press.

McKittrick, K. 2011. On plantations, prisons, and a black sense of place. Social \& Cultural Geography 12 (8): 947-963.

McKittrick K. 2013. Plantation futures. Small Axe 17(3):1-15.

McKittrick, K. 2014. Mathematics Black Life. The Black Scholar 44(2): 16-28.

McKittrick, K. 2016. Rebellion/invention/groove. Small Axe 20.1(49): 79-91.

Meyerhoff, E. and E. Noterman. 2017. Revolutionary scholarship by any speed necessary: Slow or fast but for the end of this world. ACME: an international journal for critical geographies: 1-31.

Middleton, E. 2010. A political ecology of healing. Journal of Political Ecology 17(1): 1-28.

Milstein, C. 2017. Rebellious mourning: The collective work of grief. AK Press.

Mitchell-Eaton, E. 2019. Grief as method: Topographies of grief, care, and fieldwork from Northwest Arkansas to New York and the Marshall Islands. Gender, Place \& Culture 26(10): 1438-1458.

Mol, A. 2002. The body multiple: Ontology in medical practice. Duke University Press. 
Mollett, S., and C. Faria. 2013. Messing with gender in feminist political ecology. Geoforum 45: 116-125.

Moore, D.S. 2005. Suffering for territory: Race, place, and power in Zimbabwe. Duke University Press.

Morrison, T. 2004. Beloved. Vintage International.

Mountz, A. 2017. Island detention: Affective eruption as trauma's disruption. Emotion, Space and Society 24: 74-82.

Muñoz, J. 2009. Cruising Utopia: The there and then of queer theory. New York University Press.

Murphy, M. 2017. Alterlife and decolonial chemical relations. Cultural Anthropology 32(4): 494-503.

Nast, H. 1994. Women in the Field: Critical feminist methodologies and theoretical perspectives. Professional Geographer 46: 54-66.

Naylor, L., Daigle, M., Ramírez, M.M. and Gilmartin, M., 2018. Interventions: Bringing the decolonial to political geography. Political Geography, 66: 199-209.

Neely, A. and T. Lopez. 2020. Care in the time of Covid-19. Antipode Online. https://antipodeonline.org/2020/04/04/care-in-the-time-of-covid-19/. (Last Accessed: August 12 2021).

Neumann, R.P. 1998. Imposing wilderness: Struggles over livelihood and nature preservation in Africa. University of California Press.

Nightingale, A.J. 2012. The embodiment of nature: Fishing, emotion, and the politics of environmental values. In Brady, E. and P. Phemister (eds.). Human-environment relations: Transformative values in theory and practice. Springer Netherlands.

Nixon, R. 2011. Slow violence and the environmentalism of the poor. Harvard University Press.

Paprocki, K. 2018. Threatening dystopias: development and adaption regimes in Bangladesh. Annals of the American Association of Geographers 108(4): 955-973.

Paulson, S. 2021. Decolonizing technology and political ecology futures. Political Geography. 88, 102369. https://doi.org/10.1016/j.polgeo.2021.102369

Pellow, D.N. 2007. Resisting global toxics: Transnational movements for environmental justice. MIT Press.

Peluso, N.L. 1992. The political ecology of extraction and extractive reserves in East Kalimantan, Indonesia. Development and Change 23(4): 29-74.

Peluso, N.L. and M.J. Watts (eds.). 2001. Violent environments. Cornell University Press.

Perera, S. 2010. Torturous dialogues: Geographies of trauma and spaces of exception. Continuum 24(1): 31-45.

Perry, S. 2012. Development, land use, and collective trauma: The Marcellus Shale gas boom in rural Pennsylvania. Culture, Agriculture, Food \& Environment 34(1): 81-92.

Pratt, K. 2012. Rethinking community: Conservation, practice, and emotion. Emotion, Space and Society, 5(3): 177-185.

Pulido, L. 2015. Geographies of race and ethnicity 1: White supremacy vs white privilege in environmental racism research. Progress in Human Geography 39(6): 809-817.

Raento, P. 2016. A geopolitics of the horse in Finland. Geopolitics 21(4): 945-968.

Robbins, P. 2012. Political ecology. A critical introduction. Wiley-Blackwell.

Robbins, P. 2020. Is less more... or is more less? Scaling the political ecologies of the future. Political Geography. 76, 102018. https://doi.org/10.1016/j.polgeo.2019.04.010

Robinson, C. J. 2000. Black Marxism: The making of the Black radical tradition. University of North Carolina Press.

Roy, A. 2016. Who's afraid of postcolonial theory? International Journal of Urban and Regional Research 40(1): 200-209.

Russo, A. 2018. Feminist accountability: Disrupting violence and transforming power. NYU Press.

Seamster, L., \& D. Purifoy. 2021. What is environmental racism for? Place-based harm and relational development. Environmental Sociology 7(2): 110-121.

Sharp, J., and L. Dowler. 2011. Framing the Field. In De Casino, V.J., M. Thomas, P. Cloke, and R. Panelli (eds.). A companion to social geography. Wiley. 
Sharpe, C. 2016. In the wake: On Blackness and being. Duke University Press.

Slocum, R., and K.V. Cadieux. 2015. Notes on the practice of food justice in the U.S.: Understanding and confronting trauma and inequity. Journal of Political Ecology 22(1): 27-52.

Smiles, D. 2018. "... to the Grave"-Autopsy, settler structures, and Indigenous counter-conduct. Geoforum 91: 141-150.

Smith, J.R. 2020. "Exceeding Beringia": Upending universal human events and wayward transits in Arctic spaces. Environment and Planning D: Society and Space 0: 1-18.

Smith, L.Tuhiwai . 2012. Decolonizing methodologies: Research and Indigenous peoples. 2nd ed. Zed.

Smith, S. and P. Vasudevan. 2017. Race, biopolitics, and the future: Introduction to the special section. Environment and Planning D: Society and Space 35(2): 210-221.

Sultana, F. 2011. Suffering for water, suffering from water: Emotional geographies of resource access, control and conflict. Geoforum 42(2): 163-172.

Sultana, F. 2015. Emotional political ecology. In R. Bryant (ed.). The international handbook of political ecology. Edward Elgar.

Sundberg, J. 2003. Masculinist epistemologies and the politics of fieldwork in Latin Americanist geography. Professional Geographer 55(2): 180-190.

Sundberg, J. 2014. Decolonizing posthumanist geographies. Cultural Geographies 21(1): 33-47.

Sundberg, J. 2015. Ethics, entanglement, and political ecology. In In Perreault, T., G. Bridge \& J. McCarthy (eds.). The Routledge handbook of political ecology. Routledge. Pp. 117-126.

Sundberg, J. 2017. Feminist Political Ecology. In Castree, N. et al. (eds.) International Encyclopedia of Geography: People, the Earth, Environment and Technology. Wiley.

Swyngedouw, E. 1996. The city as a hybrid: on nature, society and cyborg urbanization. Capitalism Nature Socialism 7(2): 65-80.

Sze, J. 2006. Noxious New York: The racial politics of urban health and environmental justice. MIT Press.

Thrift, N. 2004. Intensities of feeling: Towards a spatial politics of affect. Geografiska Annaler: Series B, Human Geography 86(1): 57-78.

Till, K.E. 2012. Reply: trauma, citizenship and ethnographic responsibility. Political Geography 31(1): 22-23.

Truelove, Y. 2011. (Re-)Conceptualizing water inequality in Delhi, India through a feminist political ecology framework. Geoforum 42(2): 143-152.

Tuck, E. 2009. Suspending damage: a letter to communities. Harvard Educational Review 79(3): 409-428.

Tuck, E. and K.W. Yang. 2012. Decolonization is not a metaphor. Decolonization: Indigeneity, Education \& Society $1(1)$.

Tyner, J. A., J.F. Inwood, and D.H. Alderman. 2014. Theorizing violence and the dialectics of landscape memorialization: A case study of Greensboro, North Carolina. Environment and Planning D: Society and Space 32(5): 902-914.

Tyner, J., and J. Inwood. 2014. Violence as fetish: Geography, Marxism, and dialectics. Progress in Human Geography 38(6): 771-784.

Van Dooren, T. 2014. Flight ways: Life and loss at the edge of extinction. Columbia University Press.

Van Sant, L., Milligan, R. and Mollett, S. 2021. Political ecologies of race: Settler colonialism and environmental racism in the United States and Canada. Antipode 53(3): 629-642.

Vasudevan, P. 2021. An intimate inventory of race and waste. Antipode 53(3): 770-790.

Voyles, T.B. 2015. Wastelanding: Legacies of uranium mining in Navajo country. University of Minnesota Press.

Walker, J. 2013. Moving testimonies and the geography of suffering: Perils and fantasies of belonging after Katrina. In Broderick, M. and A. Traverso (eds.). Interrogating Trauma: Collective suffering in global arts and media. Routledge. 
Watts, M.J. 1983. Silent Violence: Food, famine, and peasantry in Northern Nigeria. Berkeley: University of California Press.

Watts, M.J. and R. Peet. 1996. Towards a theory of liberation ecology. In Peet, R. and M.J. Watts (eds.). Liberation ecologies: Environment, development, social movements. Routledge.

Watts, M.J. 2015. Now and Then: The origins of political ecology and the rebirth of adaptation as a form of thought. In Perreault, T., G. Bridge \& J. McCarthy (eds.). The Routledge handbook of political ecology. Routledge. Pp. 19-50.

Watts, M.J. and S. Elden. 2015. Interview with Michael Watts: On Nigeria, political ecology, geographies of violence, and the history of the discipline. Society and Space online: http://societyandspace.com/material/interviews/interview-with-michael-watts-on-nigeria-politicalecology-geographies-of-violence-and-the-history-of-the-discipline/

Watts, M.J., M. Redclift, M. Giordano and G. Matzke. 2001. Classics in human geography revisited: Michael Watts, 'Silent Violence'. Progress in Human Geography 25(4): 621-628.

West, P. 2006. Conservation is our government now: the politics of ecology in Papua New Guinea. Duke University Press.

Whyte, K. 2017. Indigenous climate change studies: Indigenizing futures, decolonizing the Anthropocene. English Language Notes 55(1): 153-162.

Whyte, K.P. 2018. Indigenous science (fiction) for the Anthropocene: Ancestral dystopias and fantasies of climate change crises. Environment and Planning E: Nature and Space 1(1-2): 224-242.

Wilder, C.S. 2013. Ebony and Ivy: Race, slavery, and the troubled history of Americas. Bloomsbury Press.

Willis, A. 2009. Restorying the self, restoring place: Healing through grief in everyday places. Emotion, Space and Society 2(2): 86-91.

Wolfe, P. 1999. Settler colonialism. Bloomsbury Publishing.

Wolfe, P. 2006. Settler colonialism and the elimination of the Native. Journal of Genocide Research 8(4), 387409.

Wooden, A. 2014. Kyrgyzstan's dark ages: Framing and the 2010 hydroelectric revolution. Central Asian Survey 33(4): 463-481.

Woods, C.A. 2002. Life after death. The Professional Geographer 54(1): 62-66.

Woods, C.A. 1998. Development arrested: The blues and plantation power in the Mississippi Delta. Verso.

Wright, W.J. 2021. As above, so below: anti-Black violence as environmental racism. Antipode 53(3): $791-809$.

Wynter, S. 1994. No humans involved: An open letter to my colleagues. Forum NHI: Knowledge for the 21st Century 1(1): 42-73.

Ybarra, M. 2014. Don't just pay it back, pay it forward: from accountability to reciprocity in research relationships. Journal of Research Practice 10(2): 5.

Zimmer, A. 2010. Urban political ecology: Theoretical concepts, challenges, and suggested future directions. Erdkunde: 343-354. 